\title{
Kepatuhan Orang Tua dalam Membawa Penderita Thalassemia untuk Menjalani Transfusi Darah selama Pandemi COVID-19
}

\author{
Mitayani Purwoko ${ }^{1}$ dan Trisnawati Mundijo ${ }^{2}$ \\ 1,2Departemen Biologi Kedokteran, Fakultas Kedokteran, Universitas Muhammadiyah Palembang \\ mitayani@um-palembang.ac.id ${ }^{1}$ dan trisna.akbar911@gmail.com²
}

\section{ABSTRAK}

Diajukan 13 Mei 2021 Diperbaiki 20 Juni 2021 Diterima 21 Juni 2021

Latar Belakang: Pandemi coronavirus disease 2019 (COVID-19) yang disebabkan oleh virus SARS-CoV-2 di awal tahun 2020 menyebabkan Pembatasan Sosial Berskala Besar (PSBB) di Kota Palembang. Hal ini kemungkinan memengaruhi kesempatan penderita thalassemia untuk melakukan kontrol teratur dan mendapat transfusi darah karena rumah sakit rujukan thalassemia sebagian besar terletak di Kota Palembang.

Tujuan: Untuk mengetahui kepatuhan penderita thalassemia dalam melakukan transfusi selama pandemi COVID-19 dan faktor-faktor yang memengaruhinya.

Metode: Penelitian dengan desain cross-sectional ini dilakukan di Yayasan Perhimpunan Orang Tua Penderita Thalassemia Indonesia (POPTI) Kota Palembang. Populasi target dalam penelitian ini adalah orang tua dari pasien penderita thalassemia. Besar sampel adalah 77 orang. Responden diminta mengisi kuesioner tentang pengetahuan dan perilaku. Data dianalisis dengan uji chi square.

Hasil: Hasil penelitian didapatkan bahwa kepatuhan penderita thalassemia dalam melakukan transfusi darah selama masa pandemi COVID-19 masih baik (74,0\%). Hasil uji bivariat diketahui bahwa kepatuhan tidak dipengaruhi oleh tingkat pengetahuan orang tua mengenai COVID-19, usia orang tua, jenis kelamin orang tua, pekerjaan orang tua, dan pendidikan orang tua.

Kesimpulan: Kepatuhan penderita thalassemia dalam melakukan transfusi selama masa pandemi COVID-19 tetap baik.

Kata Kunci: Kepatuhan Transfusi; Thalassemia; COVID-19

\section{ABSTRACT}

Background: The 2019 coronavirus disease (COVID-19) pandemic caused by the SARS-Cov-2 virus in early 2020 caused Large-Scale Social Restrictions in Palembang City. This is likely to affect the chances of thalassemia patients to carry out regular control and receive blood transfusions because most of the referral hospitals are located in Palembang.

Objective: To determine the transfusion compliance in thalassemia patients during the COVID-19 pandemic and the factors that influence it.

Methods: This cross-sectional study was conducted at Perhimpunan Orang Tua Penderita Thalassemia Indonesia (POPTI) Foundation in Palembang. Target population was parents of thalassemia patients. The sample size was 77 subjects. Subjects were asked to fill out the questionnaires about knowledge and behavior. Data were analyzed using chi-square test.

Results: The transfusion compliance among thalassemia patients in POPTI was still good during pandemic $(74,0 \%)$. This was not influenced by the level of parental knowledge about COVID-19, parental age, parental gender, parental occupation, and parental education.

Conclusion: The compliance of thalassemia patients in carrying out transfusions during the COVID-19 pandemic is still good.

Keywords: Transfusion Compliance; Thalassemia; COVID-19 


\section{PENDAHULUAN}

Thalassemia adalah penyakit herediter akibat adanya kecacatan sintesis rantai globin yang diwariskan dengan pola autosomal resesif. Thalassemia diklasifikasikan menjadi Thalassemia $\alpha, \beta$, $\delta \beta, \gamma \delta \beta, \delta$, dan $\gamma$. Patofisiologi utama thalassemia adalah akibat terjadinya ketidakseimbangan antara rasio rantai globin $\alpha$ dan $\beta$.

Rantai globin yang tidak berikatan (yaitu rantai globin $\alpha$ pada Thalassemia $\beta$ dan rantai globin $\beta$ pada Thalassemia $\alpha$ ) mengalami presipitasi dan kemudian menyebabkan destruksi prekursor eritroid. Akibatnya, terjadi eritropoiesis yang tidak efektif di sumsum tulang dan mengakibatkan munculnya hemolysis eritrosit (Lee et al., 2011).

Penderita thalassemia mengalami kelebihan zat besi akibat sering ditransfusi darah. Kelebihan zat besi yang mengendap di jaringan dapat menyebabkan kerusakan organ-organ, misalnya hati, jantung, paru-paru, dan kelenjar endokrin sehingga hal ini dapat mengganggu sistem imun. Akibatnya, penderita Thalassemia memiliki kerentanan yang tinggi untuk terkena corona virus disease 2019 (COVID-19) (Karimi \& De Sanctis, 2020).

Penderita thalassemia mayor di RS Mohammad Hoesin Palembang tahun 2015 diketahui sebanyak 66 pasien dan penderita thalassemia $\beta$ minor pada pelajar SMK di Ciamis, Jawa Barat, pada tahun 2020 ditemukan sebanyak 3 orang (Sari et al., 2016; Setiawan et al., 2020).

Salah satu faktor yang memengaruhi kesehatan seseorang adalah perilaku kesehatan dirinya, keluarganya, dan masyarakat di sekitarnya. Perilaku kesehatan adalah suatu respons manusia terhadap rangsangan yang berkaitan dengan sakit dan penyakit, sistem pelayanan kesehatan, serta lingkungan (Adliyani, 2015). Perilaku kesehatan dalam kasus penderita thalassemia perlu dilakukan pengontrolan yang ketat, yaitu perilaku melakukan kontrol hemoglobin secara teratur dan melakukan transfusi darah.

Berdasarkan data 64 orang penderita thalassemia di Banyumas, Jawa Tengah, sebanyak $87,5 \%$ penderita melakukan transfusi darah 1 kali dalam 1 bulan di rumah sakit (Rejeki et al., 2014). Apabila transfusi tidak dilakukan, penderita thalassemia akan mengalami anemia berat dan menimbulkan hipoksia jaringan (Murtazamustafa et al., 2016).

Berdasarkan sebuah studi di Banda Aceh, terdapat perbedaan yang bermakna pada hemoglobin antara penderita thalassemia yang patuh melakukan terapi dengan yang tidak patuh (Asnani \& Rahayuningsih, 2017). Pada Desember 2019, penderita thalassemia di Rumah Singgah Thalassemia Bandar Lampung yang patuh melakukan transfusi darah hanya sebesar 65,5\% (Murtazamustafa et al., 2016).

The World Health Organization (WHO) mengumumkan adanya pandemi COVID19 yang disebabkan oleh virus SARS-CoV2 pada tanggal 11 Maret 2020. Virus ini dapat ditularkan melalui aerosol, kontak langsung ataupun tidak langsung, serta melalui prosedur medis. Gejala COVID-19 di antaranya seperti gejala flu, yang dapat disertai demam, lemah, batuk, sesak napas, bahkan kehilangan kemampuan menghidu dan mengecap rasa (Beig Parikhani et al., 2021).

$$
\text { Adanya pandemi COVID-19 }
$$
menyebabkan pemerintah pusat dan daerah menerapkan Pembatasan Sosial Berskala Besar (PSBB) di sebagian besar wilayah Indonesia, salah satunya adalah kota Palembang yang dilaksanakan pada tanggal 20 Mei 2020 hingga 16 Juni 2020 (Pemerintah Kota Palembang, 2020). Pembatasan pergerakan masyarakat oleh negara memberi pengaruh pada pelayanan kesehatan di wilayah-wilayah yang menjalankan PSBB.

Rumah sakit menutup klinik rawat jalan dan hanya menerima kasus gawat 
darurat. Adanya pembatasan layanan kesehatan ini mungkin memengaruhi kesempatan penderita thalassemia untuk melakukan kontrol teratur dan mendapat transfusi darah karena rumah sakit rujukan utama bagi penderita thalassemia terletak di Kota Palembang. Selain itu, adanya pembatasan menyebabkan stok darah di Palang Merah Indonesia (PMI) atau bank darah rumah sakit menjadi berkurang karena masyarakat dihimbau untuk tidak keluar rumah dan tidak berada di tempat pelayanan kesehatan jika tidak sangat diperlukan.

Penelitian ini bertujuan untuk mengetahui kepatuhan penderita thalassemia dalam melakukan transfusi darah selama masa pandemi COVID-19 serta faktor-faktor yang memengaruhinya. Penelitian ini dapat dijadikan dasar dalam manajemen penderita thalassemia di masa pandemi.

\section{METODE}

Penelitian observasional analitik ini menggunakan desain cross sectional. Penelitian dilakukan di Yayasan Perhimpunan Orang Tua Penderita Thalassemia Indonesia (POPTI) Kota Palembang pada September-Desember 2020. Populasi target dalam penelitian ini adalah orang tua dari para pasien penderita thalassemia di Sumatera Selatan. Populasi terjangkau dalam penelitian ini adalah orang tua dari para pasien penderita thalassemia yang tergabung dalam POPTI Palembang periode Agustus -Desember 2020.

Penelitian ini telah mendapat persetujuan etik dari Komisi Etik Fakultas Kedokteran, Kesehatan Masyarakat dan Keperawatan Universitas Gadjah Mada Yogyakarta pada tanggal 02 Oktober 2020 dengan nomor surat KE/FK/1090/EC/2020.

Besar sampel dalam penelitian ini minimal 68 orang. Kriteria inklusi bagi responden dalam penelitian adalah ayah/ ibu dari penderita thalassemia yang tergabung dalam POPTI Palembang, orang tua yang anaknya masih hidup pada saat penelitian dilakukan, dan bisa baca tulis. Kriteria eksklusi penelitian ini adalah orang tua dan anak yang tidak tinggal di Sumatera Selatan selama masa awal pandemi dan PSBB.

Sampel diambil dengan menggunakan teknik consecutive sampling. Semua subjek yang datang berurutan dan memenuhi kriteria penelitian dimasukkan dalam penelitian sampai jumlah subjek yang diperlukan terpenuhi.

Variabel bebas dalam penelitian ini adalah tingkat pengetahuan orang tua mengenai COVID-19, usia orang tua, pekerjaan orang tua, jenis kelamin orang tua, pendidikan orang tua, dan zona tempat tinggal penderita thalassemia. Zona tempat tinggal penderita yang dilihat berdasarkan alamat dan dicocokkan dengan data Dinas Kesehatan Provinsi Sumatera Selatan.

Variabel terikat dalam penelitian ini adalah kepatuhan orang tua dalam membawa penderita thalassemia untuk melakukan transfusi darah, yang dikategorikan menjadi patuh dan tidak patuh. Kategori patuh jika skor 12-15 dan dianggap tidak patuh jika skor 0-11. Data diambil secara langsung dari responden melalui pengisian kuesioner online atau kuesioner offline (fisik). Kuesioner telah melalui proses validasi.

Pertanyaan pada kategori perilaku kepatuhan berisi tiga pertanyaan untuk menilai kepatuhan orang tua membawa anaknya untuk ditransfusi sesuai jadwal. Pilihan ganda terdiri dari skala Likert dengan jawaban: tidak pernah (skor 1), jarang (skor 2), kadang-kadang (skor 3), sering (skor 4), dan selalu (skor 5).

Data dianalisis dan diinterpretasikan dengan menguji hipotesis dengan menggunakan program pengolahan data. Distribusi frekuensi variabel dianalisis secara univariat dan data hubungan antar variabel dianalisis dengan uji Chi Square. 
Kepatuhan Orang Tua dalam Membawa Penderita Thalassemia...

\section{HASIL DAN PEMBAHASAN}

Penelitian ini menerima jawaban kuesioner dari 129 responden yang terdiri dari 29 responden online dan 100 responden kuesioner fisik. Data tersebut hanya didapatkan 77 responden yang mengisi kuesioner sesuai kriteria inklusi dan eksklusi, sehingga total responden yang dianalisis adalah 77 orang. Karakteristik responden ditampilkan dalam Tabel 1.

Berdasarkan data karakteristik responden dalam Tabel 1, sebagian besar responden berjenis kelamin perempuan $(77,9 \%)$, tergolong dalam dewasa akhir $(55,8 \%)$, berpendidikan SMA atau sederajat $(53,2 \%)$, bertempat tinggal di Kota Palembang (54,5\%), dan melakukan transfusi di Rumah Sakit Muhammad Hoesin Palembang (96,1\%) meskipun tempat tinggal beberapa penderita thalassemia di luar kota Palembang. Sebanyak 40 dari 77 responden tidak bekerja $(51,9 \%)$, yang terdiri dari ibu rumah tangga sebanyak 39 orang dan pensiunan 1 orang.

Tabel 1. Karakteristik Responden ( $n=77$ orang)

\begin{tabular}{|c|c|c|c|}
\hline No & Karakter Responden & Frekuensi (orang) & Persentase $(\%)$ \\
\hline \multirow[t]{3}{*}{1} & Jenis Kelamin & & \\
\hline & Laki-laki & 17 & 22,1 \\
\hline & Perempuan & 60 & 77,9 \\
\hline \multirow[t]{7}{*}{2} & Usia (Tahun) & & \\
\hline & Remaja (18-25) & 1 & 1,3 \\
\hline & Dewasa awal (26-35) & 21 & 27,3 \\
\hline & Dewasa akhir (36-45) & 43 & 55,8 \\
\hline & Lansia awal (46-55) & 10 & 13,0 \\
\hline & Lansia akhir (56-65) & 2 & 2,6 \\
\hline & Manula (>65) & 0 & 0,0 \\
\hline \multirow[t]{3}{*}{3} & Pekerjaan & & \\
\hline & Bekerja & 37 & 48,1 \\
\hline & Tidak bekerja & 40 & 51,9 \\
\hline \multirow[t]{5}{*}{4} & Pendidikan Terakhir & & \\
\hline & SD & 5 & 6,5 \\
\hline & SMP & 16 & 20,8 \\
\hline & SMA/SMK/SMEA & 41 & 53,2 \\
\hline & D3/S1/S2 & 15 & 19,5 \\
\hline \multirow[t]{3}{*}{5} & Tempat Tinggal & & \\
\hline & Kota Palembang & 42 & 54,5 \\
\hline & Luar Kota Palembang & 35 & 45,5 \\
\hline \multirow[t]{3}{*}{6} & Rumah Sakit Tempat Transfusi Rutin & & \\
\hline & RS dalam kota Palembang & 74 & 96,1 \\
\hline & RS luar kota Palembang & 3 & 3,9 \\
\hline
\end{tabular}

Tingkat pengetahuan dan kepatuhan

darah rutin di masa pandemi dirangkum orang tua dalam membawa anak transfusi

dalam Tabel 2 di bawah ini:

Tabel 2. Kepatuhan Orang Tua (n=77 orang)

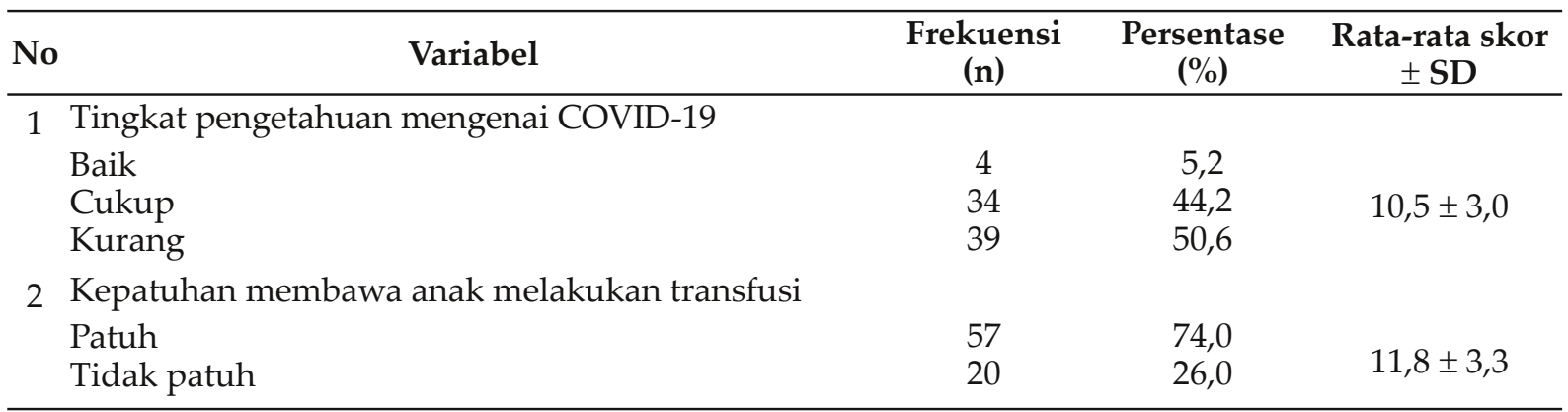


Kepatuhan Orang Tua dalam Membawa Penderita Thalassemia...

Berdasarkan Tabel 2, hanya sedikit orang tua yang memiliki tingkat pengetahuan baik mengenai COVID-19 dan thalassemia (5,2\%). Meskipun demikian, sebagian besar orang tua $(74,0 \%)$ tetap patuh membawa anaknya untuk ditransfusi pada selama masa pandemi COVID-19.
Hubungan antara tingkat pengetahuan orang tua mengenai COVID19 dan thalassemia dengan kepatuhan membawa anak melakukan transfusi selama masa pandemi COVID-19 dianalisis dengan uji Chi Square. Hasil uji Chi Square tersebut dirangkum dalam Tabel 3 di bawah ini:

Tabel 3. Hasil Uji Chi Square terhadap Kepatuhan

\begin{tabular}{cllc}
\hline No & \multicolumn{1}{c}{ Variabel terikat } & \multicolumn{1}{c}{ Variabel bebas } & $p$ \\
\hline 1 & Kepatuhan orang tua & a. Tingkat pengetahuan orang tua mengenai COVID-19 & 0,104 \\
& membawa anak untuk & b. Usia orang tua & 1,000 \\
& transfusi darah rutin selama & c. Jenis kelamin orang tua & 0,125 \\
& pandemi COVID-19 & d. Pendidikan orang tua & 0,396 \\
& e. Pekerjaan orang tua & 0,214 \\
& f. Zona COVID-19 awal pandemi & $0,041^{*}$ \\
& g. Zona COVID-19 masa PSBB & 0,058 \\
& h. Zona COVID-19 masa new normal & 0,610 \\
\hline
\end{tabular}

Keterangan: *bermakna pada level 0,05

Hasil uji Chi Square menunjukkan nilai $p<0,05$ untuk variabel bebas zona tempat tinggal penderita di masa pandemi COVID-19 sebelum PSBB. Hal ini menunjukkan bahwa lokasi tempat tinggal penderita thalassemia di zona hijau (Gambar 1) memengaruhi kepatuhan transfusi di masa sebelum PSBB. Namun, ketika telah diberlakukan PSBB Kota Palembang dan ketika masa new normal, lokasi tempat tinggal penderita tidak lagi memengaruhi kepatuhan karena persebaran zona risiko tinggi hampir merata di Provinsi Sumatera Selatan (Gambar 2).

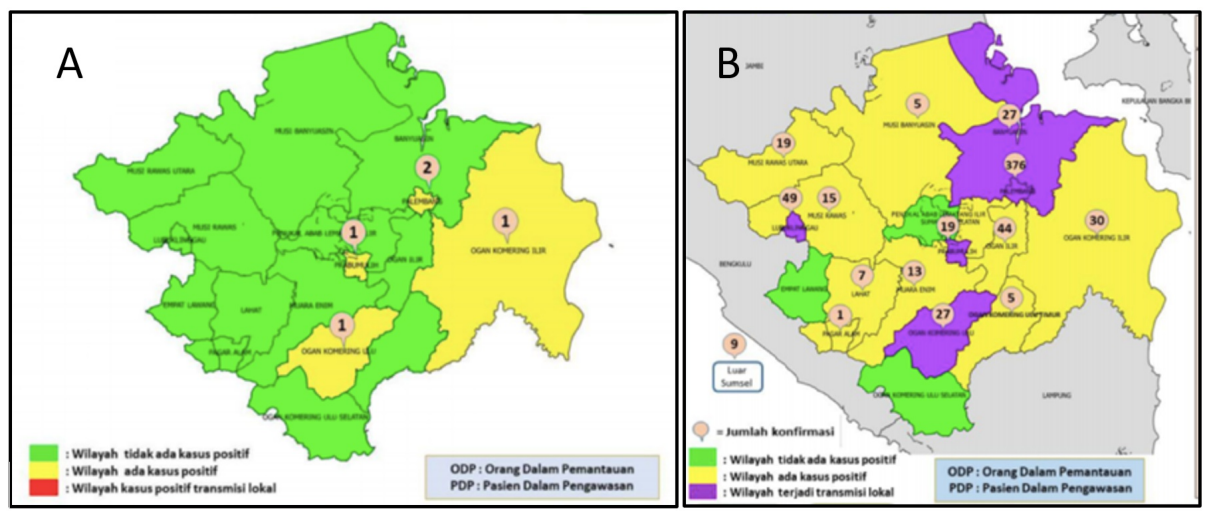

Gambar 1. Peta Zona COVID-19 pada masa sebelum (Gambar A) dan saat PSBB (Gambar B) Kota Palembang (Dinas Kesehatan Sumatera Selatan, 2020a, 2020b)



Gambar 2. Peta Zona COVID-19 pada masa New Normal Kota Palembang (Dinas Kesehatan Sumatera Selatan, 2020c) 
Faktor genetik dalam perjalanan penyakit thalassemia merupakan salah satu faktor yang menyebabkan perjalanan penyakit ini tidak dapat diubah atau disembuhkan. Peningkatan kepatuhan orang tua dalam membawa penderita thalassemia untuk melakukan transfusi darah adalah hal yang penting untuk dilakukan agar dapat meningkatkan usia harapan hidup penderita dan juga mengurangi timbulnya komplikasi (Ghorbanpoor et al., 2020).

Setelah menerima tranfusi darah, penderita thalassemia akan mendapatkan terapi kelasi besi yang berfungsi untuk mengurangi penumpukan zat besi di dalam tubuh akibat transfusi rutin. Salah satu faktor yang menyebabkan efek positif pada kepatuhan penderita mendapatkan terapi kelasi besi adalah adanya dukungan keluarga yang baik (Lee et al., 2011). Dukungan keluarga yang rendah dapat menyebabkan ketidakpatuhan penderita thalassemia untuk mendapatkan terapi kelasi besi (Evangeli et al., 2010).

Berdasarkan penelitian ini, tampak bahwa kepatuhan orang tua membawa anak untuk ditransfusi tetap baik meskipun ada ancaman infeksi virus SARS-Cov-2 bagi penderita thalassemia maupun orang tua yang mengantarnya. Ancaman infeksi ini bisa timbul pada saat perjalanan pergi ke dan pulang dari rumah sakit, pada saat berada di kawasan rumah sakit, dan pada saat melakukan transfusi.

Kepatuhan ini tidak dipengaruhi oleh usia orang tua, pekerjaan orang tua, pendidikan orang tua, dan tingkat pengetahuan orang tua mengenai COVID19. Kepatuhan sangat dipengaruhi oleh psikologis penderita, yang tentunya dipengaruhi oleh berbagai faktor lain seperti faktor keluarga, sosial, budaya dan kesehatan mental penderita (Shah \& Kaltsounis, 2018).

Salah satu faktor keluarga yang penting bagi penderita thalassemia adalah perilaku orang tua yang tetap patuh membawa anaknya menjalani tranfusi secara rutin. Angka kepatuhan dalam penelitian ini lebih tinggi daripada hasil penelitian terdahulu pada penderita thalassemia di Lampung yang hanya 65,5\% (Mustofa et al., 2020).

Ali et al., (2021) melaporkan adanya penurunan penggunaan packed red blood cells (PRBC) untuk transfusi darah bagi penderita thalassemia secara signifikan $(p=0,002)$ dan penurunan jumlah pasien thalassemia yang menerima transfusi darah sebesar 10,56\%. Hasil penelitian tersebut tidak sejalan dengan penelitian ini.

Hasil penelitian ini, bagaimanapun juga, sejalan dengan penelitian (Dehshal et al., 2020) pada penderita thalassemia di Iran. Sebanyak $70 \%$ responden penelitian tersebut mengaku bahwa COVID-19 tidak memberi dampak bagi frekuensi transfusi darah mereka maupun jumlah kantong darah yang mereka terima saat transfusi.

Berdasarkan data Dinas Kesehatan Provinsi Sumatera Selatan, zona hijau adalah zona tanpa kasus positif COVID19 , zona kuning adalah zona dengan kasus positif COVID-19, serta zona ungu adalah zona dengan kasus positif dan terjadi transmisi penyakit secara lokal (Dinas Kesehatan Sumatera Selatan, 2020a, 2020b). Pada teorinya, orang tua penderita thalassemia yang tinggal di zona hijau pada masa awal pandemi akan lebih patuh mengajak anaknya menjalani tranfusi darah dibandingkan mereka yang tinggal di zona kuning atau oranye karena tidak ada kekhawatiran untuk tertular COVID19.

Hasil penelitian ini membuktikan hal tersebut $(p<0,05)$. Namun, ternyata penelitian ini menemukan bahwa orang tua di zona yang tidak hijau tetap patuh membawa anaknya menjalani transfusi. Hal ini tidak sesuai dengan hipotesis yang ditetapkan sehingga dapat disimpulkan bahwa, di zona apapun penderita Thalassemia tinggal, para orang tua akan tetap berusaha menjalani terapi demi kesehatan anaknya. 
KESIMPULAN

Kepatuhan orang tua dalam membawa anaknya penderita thalassemia untuk melakukan transfusi darah secara rutin tetap tinggi meskipun dalam masa pandemi COVID-19. Kepatuhan dipengaruhi oleh lokasi tempat tinggal penderita di masa awal pandemi. Kepatuhan orang tua yang sudah baik ini perlu ditingkatkan dengan cara meningkatkan tingkat pengetahuan orang tua mengenai tatalaksana thalassemia serta mengenai pencegahan dari terinfeksi penyakit COVID-19 di masa pandemi ini.

\section{UCAPAN TERIMA KASIH}

Peneliti mengucapkan terima kasih kepada Pimpinan Pusat Muhammadiyah atas dana Hibah Riset Mu Batch 4 Majelis Diktilitbang Pimpinan Pusat Muhammadiyah, dan pengelola yayasan POPTI Kota Palembang atas izin penelitian serta bantuannya dalam pengambilan data.

\section{DAFTAR PUSTAKA}

Adliyani, Z. O. N. (2015). Pengaruh Perilaku Individu terhadap Hidup Sehat. Perubahan Perilaku Dan Konsep Diri Remaja Yang Sulit Bergaul Setelah Menjalani Pelatihan Keterampilan Sosial, 4(7), 109-114.

Ali, S. A., Azim, D., Hassan, H. ., Iqbal, A., Ahmed, N., Kumar, S., \& Nasim, S. (2021). The impact of COVID-19 on transfusion-dependent thalassemia patients of Karachi, Pakistan: A singlecenter experience. Transfusion Clinique et Biologique, 28(January), 60-67. https://doi.org/10.1016/

j.tracli.2020.10.006

Asnani, \& Rahayuningsih, S. I. (2017). Hemoglobin Anak Thaasemia Yang Patuh Dan Tidak Patuh Dalam Menjalani Terapi. Universitas Syiah Kuala Banda Aceh, 1-8.

Beig Parikhani, A., Bazaz, M., Bamehr, H., Fereshteh, S., Amiri, S., Salehi-Vaziri, M., Arashkia, A., \& Azadmanesh, K.
(2021). The Inclusive Review on SARS-CoV-2 Biology, Epidemiology, Diagnosis, and Potential Management Options. Current Microbiology, 78(4), 1099-1114. https://doi.org/10.1007/ s00284-021-02396-x

Dehshal, M. H., Hosoya, S., Bahremani, F. H., Namini, M. T., \& Eleftheriou, A. (2020). COVID-19 and Thalassaemia in Iran. Thalassemia Reports, 10(1), 21$24 . \quad$ https://doi.org/10.4081/ thal.2020.9157

Dinas Kesehatan Sumatera Selatan. (2020a). Update COVID19 Sumsel 01 April 2020. Available from: http:// dinkes.sumselprov.go.id/2020/04/ update-covid19-sumsel-1-april-2020/

Dinas Kesehatan Sumatera Selatan. (2020b). Update COVID19 Sumsel 20 Mei 2020. Available from: http:// dinkes.sumselprov.go.id/2020/05/ update-n-cov19-sumsel-20-mei-2020/

Dinas Kesehatan Sumatera Selatan. (2020c). Update COVID19 Sumsel 25 September 2020. Available from: http:// dinkes.sumselprov.go.id/2020/09/ update-covid-19-sumsel-25-09-2020/

Evangeli, M., Mughal, K., \& Porter, J. B. (2010). Which psychosocial factors are related to chelation adherence in thalassemia a systematic review. Hemoglobin, 34(3), 305-321. https:// doi.org/10.3109/03630269.2010.485080

Ghorbanpoor, M., Mirzaie, M., Mirhaghjou, S. N., \& Roshan, Z. A. (2020). The Relationship Between Psychosocial Status and Adherence to Treatment Regimen in Adolescents With Thalassemia. Journal of Holistic Nursing and Midwifery, 30(2), 78-85. https://doi.org/10.32598/jhnm.30.2.78

Karimi, M., \& De Sanctis, V. (2020). Implications of SARSR-COV 2 infection in thalassemia s: Do patients fall into the 'high clinical risk' category? Acta Biomedica, 91(2), 50-56. https://doi.org/10.23750/ abm.v91i2.9592

Lee, W. S., Toh, T. H., Chai, P. F., \& Soo, T. 
Kepatuhan Orang Tua dalam Membawa Penderita Thalassemia...

L. (2011). Self-reported level of and factors influencing the compliance to desferrioxamine therapy in multitransfused thalassaemias. Journal of Paediatrics and Child Health, 47(8), 535-540. https://doi.org/10.1111/j.14401754.2011.02017.x

Murtazamustafa, Thiru, A., Iiizam, E., Firdaus, H., Sharifa, A., Fairrul, K., \& Nang, M. (2016). Pathophysiology, Clinical Manifestations, andCarrier DetectioninThalassemia. IOSR Journal of Dental and Medical Sciences, 15(11), 2279-2861. https://doi.org/ 10.9790/0853-151107122126

Mustofa, F. L., Triswanti, N., Rukmono, P., \& Satriadi, M. F. (2020). Hubungan Kepatuhan Transfusi Darah Terhadap Pertumbuhan Anak Thalassemia Di Rumah Singgah Thalassemia Bandar Lampung. Jurnal Medika Malahayati, 4(2), 130-136.

Pemerintah Kota Palembang. (2020). PSBB Palembang Resmi Diberlakukan. Available from: https:// www.palembang.go.id/new/berita/ read/1100/PSBB Palembang Resmi
Diberlakukan

Rejeki, D. S. S., Pradani, P., Nurhayati, N., \& Supriyanto, S. (2014). Model Prediksi Kebutuhan Darah untuk Penderita Talasemia Mayor. Kesmas: National Public Health Journal, 8(7), 295. https://doi.org/10.21109/

kesmas.v0i0.368

Sari, D. M., Aditiawati, A., Bahar, E., \& Sari, D. P. (2016). Akurasi Kadar Ferritin Serum dan Saturasi Transferin dalam Memprediksi Laju Pertumbuhan Pasien Thalassemia Mayor. Sari Pediatri, 18(2), 87. https:// doi.org/10.14238/sp18.2.2016.87-92

Setiawan, D., Farihatun, A., \& Nurmalasari, A. (2020). Skrining Talasemia Beta Minor pada Pelajar SMK di Kecamatan Ciamis. Jurnal Kesehatan Vokasional, 5(3), 180. https:// doi.org/10.22146/jkesvo.57621

Shah, F., \& Kaltsounis, G. (2018). Adherence to treatment: Doctor vs patient perspective. Thalassemia Reports, 8(1). https://doi.org/10.4081/ thal.2018.7484 